\title{
SISTEM PAKAR DIAGNOSA PENYAKIT UDANG VANNAMEI MENGGUNAKAN METODE FORWARD CHAINING BERBASIS WEB
}

\author{
Sindhu Rakasiwi \\ Program Studi Manajemen Informatika \\ Stekom Semarang \\ Email: sindhu@stekom.ac.id \\ Taqius Shofi Albastomi \\ Program Studi Manajemen Informatika \\ Stekom Semarang \\ Email: animemoster@gmail.com
}

\begin{abstract}
ABSTRAK
Budidaya udang vannamei merupakan usaha yang menjadi pilihan utama dewasa ini oleh para petani tambak udang dan juga para pembudidaya udang. Ketahanan terhadap stress dan cuaca yang ekstrim merupakan alasan utama populernya budidaya udang jenis vannamei ini. Meskipun begitu ,tak dapat dihindari ada beberapa penyakit yang dapat menyerang udang budidaya bila tak diperhatikan dengan baik. Beberapa penyakit yang menyerang udang vannamei biasanya dapat dicegah oleh para pembudidaya udang dengan berdasarkan oleh beberapa pengalaman ,namun hal ini tentunya masih kurang efektif dalam mencegah atau mengetahui jenis penyakit yang menyerang pada udang. Sistem pakar yang mengadopsi kepakaran manusia kedalam computer memiliki kedudukan strategis untuk membantu menyelesaikan permasalah penyakit yang menyerang udang vannamei. Dalam system ini inferensi yang digunakan adalah forward chaining karena proses yang dilakukan mengenali penyakit dari gejala - gejala dan ciri - ciri awal penyakit. Pembangunan sistem ini berbasis web dengan menggunakan bahasa pemrograman PHP dan appserver sebagai databasenya. Sistem pakar ini dapat mewakili seorang pakar dalam bidang penyakit udang untuk mengetahui penyakit pada udang vannamei berdasarkan ciri ciri dan gejala yang ada serta dapat memberikan solusi jika terdapat penyakit yang diderita oleh udang.
\end{abstract}

Kata kunci: sistem pakar, forward chaining, penyakit udang, udang vannamei.

\section{ABSTRACT}

Vannamei shrimp farming is the main choice today by shrimp farmers and shrimp farmers. Resilience to stress and extreme weather are the main reasons for the popularity of this type of vannamei shrimp farming. However, inevitably there are some diseases that can attack shrimp culture if not properly observed. Some diseases that attack vannamei shrimp can usually be prevented by shrimp farmers based on some experience, but this is certainly less effective in preventing or knowing the type of disease that attacks on the shrimp. Expert systems that adopt human expertise into the computer have a strategic position to help solve the problem of disease that attacks vannamei shrimp. In this system the inference used is forward chaining because the process is done to recognize the disease of the symptoms symptoms and early characteristics of the disease. The development of this system is web based using PHP programming language and appserver as its database. This expert system can represent an expert in the field of shrimp disease to know the disease on vannamei shrimp based on the characteristics and symptoms that exist and can provide a solution if there is a disease suffered by shrimp.

Keywords: expert system, forward chaining, shrimp disease, vannamei shrimp.

\section{PENDAHULUAN}

Udang vannamei merupakan komoditas unggulan yang banyak diminati untuk dibudidayakan dewasa ini. Udang vannamei merupakan udang asli dari pantai pasifik barat Amerika Latin, diperkenalkan di Tahiti pada awal tahun 1970 untuk penelitian potensi wilayah. Daya tahan udang vannamei terhadap berbagai macam penyakit yang menyerang udang pada umumnya menjadikan udang ini diminati banyak pembudidaya dan petambak udang di Indonesia.

Munculnya beberapa penyakit yang menyerang udang vannamei berdampak terhadap menurunya hasil panen. Diperlukan sebuah usaha untuk mencegah dan mengatasi beberapa penyakit yang dapat 
menyerang udang. Keahlian seorang pakar dalam bidang penyakit udang dibutuhkan untuk dapat memberikan solusi pencegahan dan penanganan yang tepat untuk setiap penyakit yang menyerang udang. Namun, seorang pakar tidak dapat setiap saat berada di tempat ketika udang terserang penyakit karena jam kerja pakar rata-rata hanya 8 jam. Oleh karena itu, dibutuhkan aplikasi bantu yang dapat mewakili seorang pakar mendiagnosa penyakit berdasarkan gejala klinis.

Seiring dengan berkembangnya teknologi komputer, keahlian dari seorang pakar dapat direpresentasikan dalam sebuah sistem, yaitu sistem pakar. Pengetahuan dari suatu sistem pakar mungkin dapat direpresentasikan dalam sejumlah cara. Salah satu metode yang paling umum untuk merepresentasikan pengetahuan adalah dalam bentuk tipe aturan (rule) IF...THEN (jika.....maka). Walaupun cara tersebut sangat sederhana, namun banyak hal yang berarti dalam membangun sistem pakar dengan mengekspresikan pengetahuan pakar dalam aturan tersebut. Terdapat dua pendekatan untuk mengontrol inferensi dalam sistem pakar berbasis aturan, yaitu pelacakan kedepan (forward chaining) dan pelacakan kebelakang (backward chaining). Pelacakan kedepan dapat dijelaskan sebagai suatu rantai yang melakukan pelacakan dari informasi masukan suatu fakta untuk memperoleh solusi atau konklusi dari fakta. Sedangkan pelacakan kebelakang memulai pelacakan dari tujuan, selanjutnya dicari aturan yang memiliki tujuan tersebut untuk kesimpulannya [1].

Berdasarkan pada permasalahan diatas, diperlukan sebuah sistem yang dapat melakukan identifikasi terhadap jenis penyakit yang menyerang udang vannamei berdasarkan gejala klinis. Sistem tersebut adalah sebuah sistem pakar yang dapat memberikan sebuah solusi pencegahan dari penyakit yang diketahui dari penelusuran gejala klinis. Oleh karena itu, penulis memberikan sebuahusulan untuk membuat sistem pakar dengan menggunakan metode forward chaining.

\section{METODOLOGI PENELITIAN}

Secara konseptual, pendekatan penelitian dan pengembangan dalam penelitian ini merujuk pada metode penelitian dan pengembangan Research and Development (R\&D). R\&D adalah metode penelitian yang digunakan untuk menghasilkan produk tertentu, dan menguji keefektifan produk tersebut. Menurut (Sugiyono, 2008) metode R\&D mencakup 10 langkah umum, namun penulis hanya menerapkan enam langkah pertama dalam pengembangan produk dalam penelitian ini, yaitu sebagai berikut:

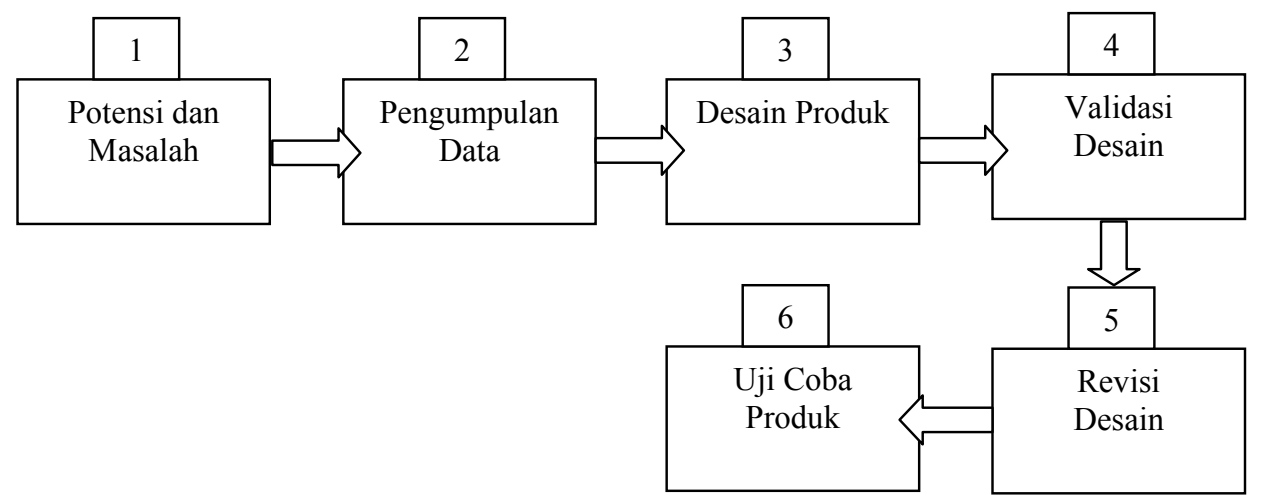

Gambar 1. Langkah - Langkah Penggunaan Metode Research And Development (R\&D)

Suatu perkalian inferensi yang menghubungkan suatu permasalahan dengan solusinya disebut dengan rantai (chain). Suatu rantai yang dicari atau dilewati /dilintasi dari suatu permasalahan untuk memperoleh solusinya disebut dengan forward chaining. Cara lain menggambarkan forward chaining ini adalah dengan penalaran dari fakta menuju konklusi yang terdapat dari fakta [1].

Forward chaining disebut juga penalaran dari bawah ke atas karena penalaran dari evidence (fakta) pada level bawah menuju konklusi pada level atas didasarkan pada fakta. Penalaran dari bawah ke atas dalam suatu sistem pakar dapat disamakan untuk pemrograman konvensional dari bawah ke atas. Tingkat akurasi penarikan kesimpulan berdasarkan fakta-fakta pada forward chaining adalah 95\% [4]. 


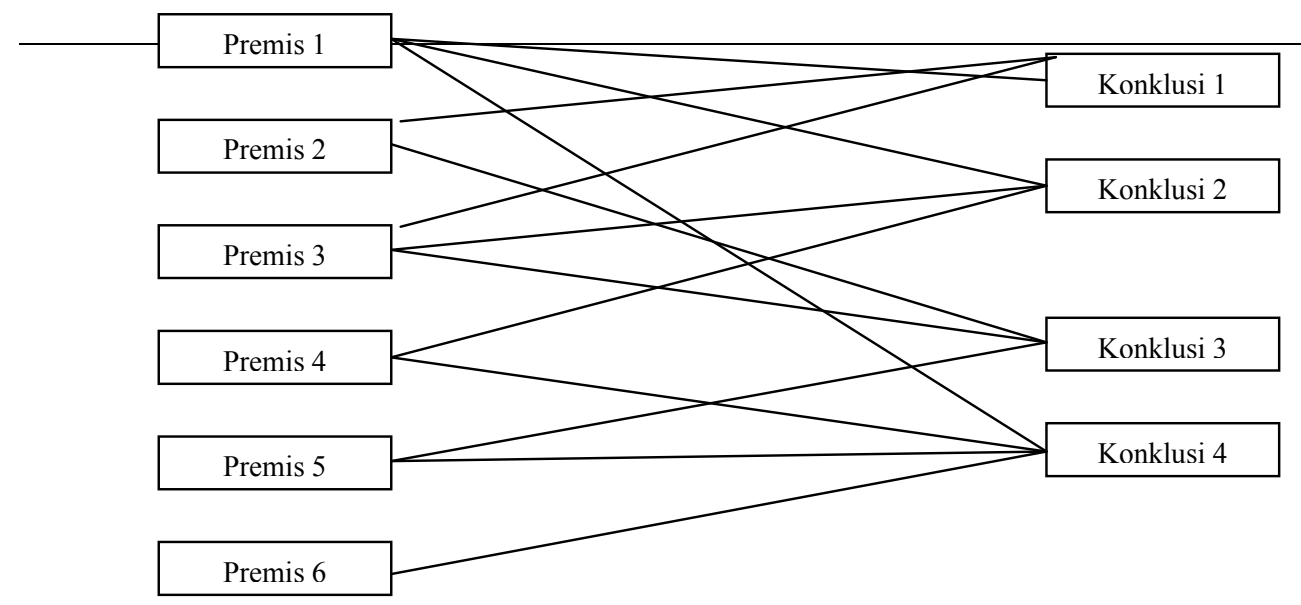

Gambar 2. Contoh Aturan Pada Forward Chaining [3]

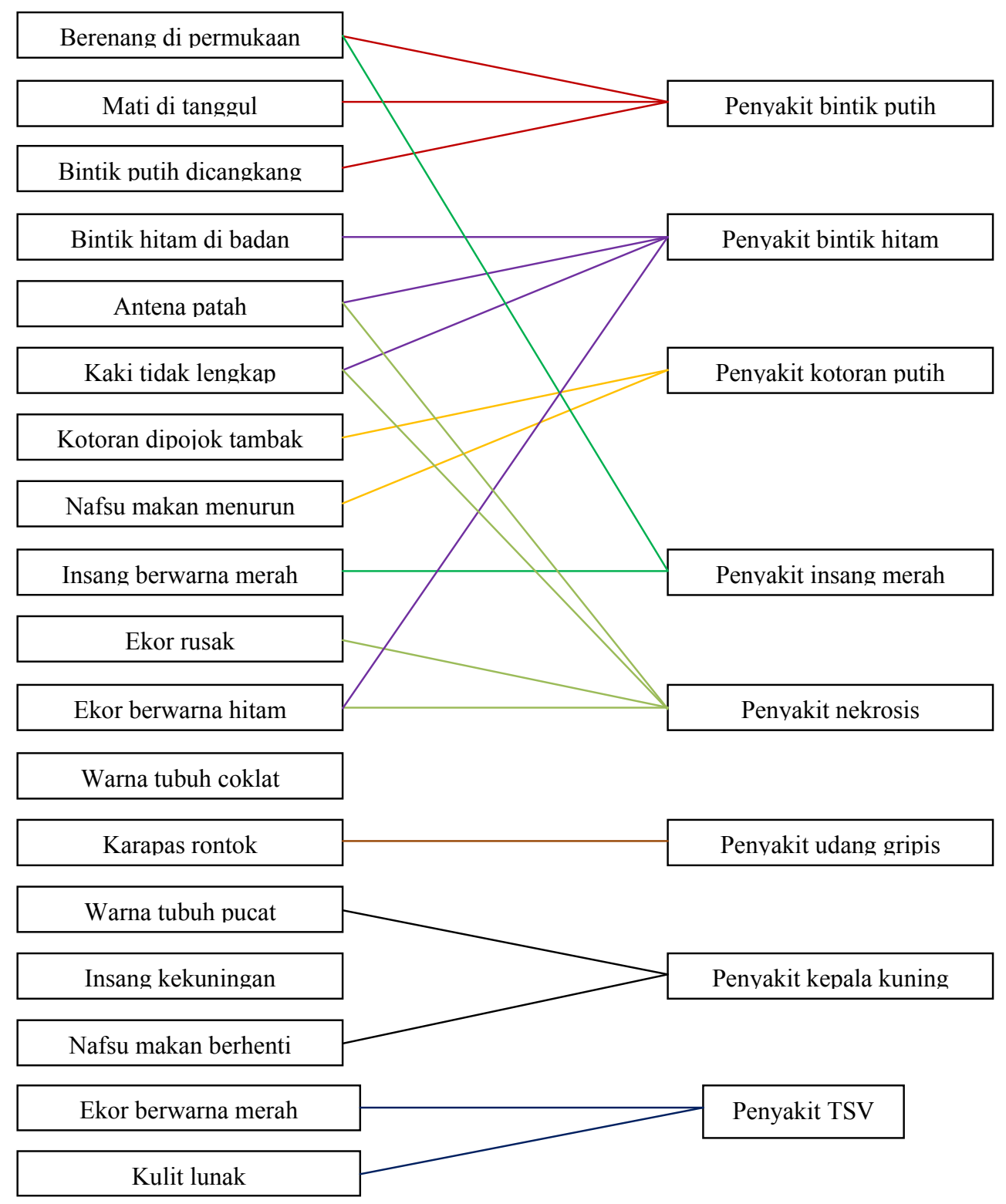

Gambar 3. Aturan Forward Chaining Diagnosa Penyakit Udang Vannamei

Di bawah ini merupakan tabel aturan gejala penyakit terhadap penyakit pada sistem pakar diagnosa penyakit udang vannamei. 
Tabel 1. Aturan gejala terhadap penyakit

\begin{tabular}{|c|c|c|c|c|c|c|c|c|c|}
\hline \multirow[b]{2}{*}{ No } & \multirow[b]{2}{*}{ Gejala } & \multicolumn{8}{|c|}{ Penyakit } \\
\hline & & $\begin{array}{l}\text { Bintik } \\
\text { Putih }\end{array}$ & $\begin{array}{l}\text { Bintik } \\
\text { Hitam }\end{array}$ & $\begin{array}{l}\text { Kotoran } \\
\text { Putih }\end{array}$ & $\begin{array}{l}\text { Insang } \\
\text { Merah }\end{array}$ & Nekrosis & $\begin{array}{l}\text { Udang } \\
\text { Gripis }\end{array}$ & $\begin{array}{l}\text { Kepala } \\
\text { Kuning }\end{array}$ & $T S V$ \\
\hline 1 & $\begin{array}{l}\text { Berenang ke } \\
\text { permukaan }\end{array}$ & $\mathrm{v}$ & - & 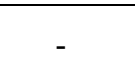 & $\mathrm{v}$ & - & - & 0 & - \\
\hline 2 & Mati ditanggul & $\mathrm{v}$ & - & - & - & - & - & - & - \\
\hline 3 & $\begin{array}{l}\text { Bintik putih di } \\
\text { kulit }\end{array}$ & $\mathrm{v}$ & - & - & - & - & - & - & - \\
\hline 4 & $\begin{array}{l}\text { Bintik hitam } \\
\text { di badan }\end{array}$ & - & $\mathrm{v}$ & - & - & - & - & - & - \\
\hline 5 & Antena patah & - & $\mathrm{v}$ & - & - & $\mathrm{v}$ & - & - & - \\
\hline 6 & $\begin{array}{l}\text { Kaki tidak } \\
\text { lengkap }\end{array}$ & - & $\mathrm{v}$ & - & - & $\mathrm{v}$ & - & - & - \\
\hline 7 & $\begin{array}{l}\text { Kotoran } \\
\text { dipojok } \\
\text { tambak }\end{array}$ & - & - & $\mathrm{v}$ & - & - & - & - & - \\
\hline 8 & $\begin{array}{l}\text { Nafsu makan } \\
\text { menurun }\end{array}$ & - & - & $\mathrm{v}$ & - & - & - & - & - \\
\hline 9 & $\begin{array}{l}\text { Insang } \\
\text { berwarna } \\
\text { merah }\end{array}$ & - & - & - & $\mathrm{v}$ & - & - & - & - \\
\hline 10 & Ekor rusak & - & - & - & - & $\mathrm{v}$ & - & - & - \\
\hline 11 & $\begin{array}{l}\text { Ekor berwarna } \\
\text { hitam }\end{array}$ & - & $\mathrm{v}$ & - & - & $\mathrm{v}$ & - & - & - \\
\hline 12 & $\begin{array}{l}\text { Warna tubuh } \\
\text { coklat }\end{array}$ & - & - & - & - & - & $\mathrm{v}$ & - & - \\
\hline 13 & $\begin{array}{l}\text { Karapas } \\
\text { rontok }\end{array}$ & - & - & - & - & - & $\mathrm{v}$ & - & - \\
\hline 14 & $\begin{array}{l}\text { Warna tubuh } \\
\text { pucat }\end{array}$ & - & - & - & - & - & - & $\mathrm{v}$ & - \\
\hline 15 & $\begin{array}{l}\text { Insang } \\
\text { kekuningan }\end{array}$ & - & - & - & - & - & - & $\mathrm{v}$ & - \\
\hline 16 & $\begin{array}{l}\text { Nafsu makan } \\
\text { berhenti }\end{array}$ & - & - & - & - & - & $\mathrm{v}$ & $\mathrm{v}$ & - \\
\hline 17 & $\begin{array}{l}\text { Ekor berwarna } \\
\text { merah }\end{array}$ & - & - & - & - & - & - & - & $\mathrm{v}$ \\
\hline 18 & Kulit lunak & - & - & - & - & - & - & - & $\mathrm{v}$ \\
\hline
\end{tabular}

Solusi pencegahan untuk setiap penyakit pada udang vannamei adalah sebagai berikut :

Tabel 2. Solusi pencegahan setiap penyakit [2]

\begin{tabular}{cl}
\hline Nama Penyakit & \multicolumn{1}{c}{ Solusi Pencegahan } \\
\hline Bintik Putih & Upaya pencegahan yang dapat dilakukan terhadap penyakit ini adalah dengan \\
& melakukan tindakan mengisolasi daerah yang sedang terserang penyakit serta \\
& pemusnahan dengan jalan pembakaran dan penguburan terhadap udang yang \\
& terindikasi terserang penyakit agar penyakit tidak menyebar luas. Kemudian \\
& melakukan upaya penanggulangan agar udang yang masih sehat terhindar dari \\
& serangan penyakit bintik putih, yaitu dengan cara mengganti air secara rutin \\
& setiap hari minimal 5\% dari total volume air tambak. \\
& Pencegahan pada penyakit ini dapat dilakukan dengan membersihkan dasar \\
& tambak dari kotoran sisa pakan dan sisa moulting selanjutnya menjaga kualitas \\
& air. \\
& Cara pencegahan yang dapat dilakukan yaitu dengan membersihkan dan \\
& mengeluarkan kotoran yang berada di tambak baik di permukaan dan di dasar \\
Kotoran Putih Hitam & tambak kemudian dilakukan pembersihan secara rutin serta menjaga kualitas air \\
& tambak. \\
& Pencegahan yang dapat dilakukan yaitu dengan melakukan penebaran kapur
\end{tabular}




\begin{tabular}{ll}
\hline Nama Penyakit & \multicolumn{1}{c}{ Solusi Pencegahan } \\
\hline \multirow{3}{*}{ Nekrosis } & pada kolam budidaya. \\
& Pencegahan dapat dilakukan dengan penggantian air sebanyak-banyaknya \\
& ditambah perlakuan TON (Tambak Organik Natural) 1-2 botol/ha, sedangkan \\
& pada udang dirangsang untuk segera melakukan ganti kulit (moulting) dengan \\
& pemberian kapur pada tambak. \\
& Pencegahan pada penyakit ini dapat dilakukan dengan cara memberikan \\
& antibiotika melalui pencampuran dengan telur ayam atau telur bebek mentah \\
& dengan perbandingan 1 butir telur untuk 10 kg pakan. Campuran telur dan \\
& antibiotika diaduk dengan pakan dan dikeringkan ditempat yang teduh lalu \\
& ditebar ke dalam tambak. Dosis yang digunakan untuk penggunaan antibiotika \\
& adalah Terramycin 30 mg/kg pakan, Erythromycin 40 mg/kg pakan, \\
& Oxytetracyclin 40-50 mg/kg pakan, Furanace 100 mg/kg pakan.Pemberian \\
& antibiotika dalam pakan dilakukan terus-menerus selama 3 hingga 5 hari, \\
& kecuali untuk furanace diberikan selama 14 hari. \\
& Upaya pencegahan yang dapat dilakukan terhadap penyakit ini adalah dengan \\
& melakukan tindakan mengisolasi daerah yang sedang terserang penyakit serta \\
& pemusnahan dengan jalan pembakaran dan penguburan terhadap udang yang \\
& terindikasi terserang penyakit agar penyakit tidak menyebar luas. Kemudian \\
Kepala Kuning & melakukan upaya penanggulangan agar udang yang masih sehat terhindar dari \\
& serangan penyakit bintik putih, yaitu dengan cara mengganti air secara rutin \\
& setiap hari minimal 5\% dari total volume air tambak. \\
& Upaya pencegahan yang dapat dilakukan yaitu dengan menjaga kualitas air \\
& dengan memberikan probiotik, jangan lakukan sirkulasi pergantian air, \\
& mengurangi pakan hingga 50\%, pemberian mineral dolomite untuk \\
& mempercepat pengerasan kulit, serta pemberian vitamin dan imunostimulan. \\
\hline Taura Syndrome &
\end{tabular}

\section{HASIL DAN PEMBAHASAN}

\subsection{Perencanaan Sistem}

Dengan munculnya jenis penyakit udang yang dapat menyerang udang jenis vannamei, serta kurangnya tenaga ahli di UD. Toriz Putra yang dapat mendiagnosa penyakit berdasarkan gejala klinis, maka diperlukan suatu langkah yang tepat untuk mengetahui jenis penyakit yang menyerang udang berdasarkan gejala-gejala yang terjadi secara tepat dan cepat. Pemanfataan teknologi komputer dapat digunakan untuk membantu petugas tambak di UD. Toriz Putra untuk mendiagnosa jenis penyakit berdasarkan gejala-gejala yang dialami oleh udang.

Adapun penelitian yang didapat penulis adalah berupa jenis penyakit, gejala, serta solusi pencegahannya. Hasil yang diperoleh dapat dijelaskan pada tabel sebagai berikut :

Tabel 3. Gejala-gejala penyakit

\begin{tabular}{cl}
\hline No & \multicolumn{1}{c}{ Gejala } \\
\hline 1 & Berenang di permukaan \\
2 & Mati di tanggul \\
3 & Bintik putih di cangkang \\
4 & Insang berwarna merah \\
5 & Ekor berwarna hitam \\
6 & Ekor rusak \\
7 & Bintik hitam di badan \\
8 & Antena patah \\
9 & Kaki tidak lengkap \\
10 & Kotoran di pojok tambak \\
11 & Nafsu makan menurun \\
12 & Nafsu makan berhenti \\
13 & Warna tubuh coklat \\
14 & Karapas rontok
\end{tabular}




\begin{tabular}{cl}
\hline No & \multicolumn{1}{c}{ Gejala } \\
\hline 15 & Warna tubuh pucat \\
16 & Insang kekuningan \\
17 & Ekor berwarna merah \\
18 & Kulit lunak \\
\hline
\end{tabular}

Tabel 4. Jenis penyakit

\begin{tabular}{ll}
\hline No & \multicolumn{1}{c}{ Nama Penyakit } \\
\hline 1 & Bintik Putih \\
2 & Bintik Hitam \\
3 & Kotoran Putih \\
4 & Insang Merah \\
5 & Nekrosis \\
6 & Udang Gripis \\
7 & Kepala Kuning \\
8 & Taura Syndrome Virus \\
\hline
\end{tabular}

Tabel 5. Solusi penyakit

\begin{tabular}{|c|c|}
\hline Nama Penyakit & Solusi Pencegahan \\
\hline Bintik Putih & $\begin{array}{l}\text { Upaya pencegahan yang dapat dilakukan terhadap penyakit ini adalah } \\
\text { dengan melakukan tindakan mengisolasi daerah yang sedang terserang } \\
\text { penyakit serta pemusnahan dengan jalan pembakaran dan penguburan } \\
\text { terhadap udang yang terindikasi terserang penyakit agar penyakit tidak } \\
\text { menyebar luas. Kemudian melakukan upaya penanggulangan agar } \\
\text { udang yang masih sehat terhindar dari serangan penyakit bintik putih, } \\
\text { yaitu dengan cara mengganti air secara rutin setiap hari minimal } 5 \% \\
\text { dari total volume air tambak. }\end{array}$ \\
\hline Bintik Hitam & $\begin{array}{l}\text { Pencegahan pada penyakit ini dapat dilakukan dengan membersihkan } \\
\text { dasar tambak dari kotoran sisa pakan dan sisa moulting selanjutnya } \\
\text { menjaga kualitas air. }\end{array}$ \\
\hline Kotoran Putih & $\begin{array}{l}\text { Cara pencegahan yang dapat dilakukan yaitu dengan membersihkan dan } \\
\text { mengeluarkan kotoran yang berada di tambak baik di permukaan dan di } \\
\text { dasar tambak kemudian dilakukan pembersihan secara rutin serta } \\
\text { menjaga kualitas air tambak. }\end{array}$ \\
\hline Insang Merah & $\begin{array}{l}\text { Pencegahan yang dapat dilakukan yaitu dengan melakukan penebaran } \\
\text { kapur pada kolam budidaya. }\end{array}$ \\
\hline Nekrosis & $\begin{array}{l}\text { Pencegahan dapat dilakukan dengan penggantian air sebanyak- } \\
\text { banyaknya ditambah perlakuan TON (Tambak Organik Natural) 1-2 } \\
\text { botol/ha, sedangkan pada udang dirangsang untuk segera melakukan } \\
\text { ganti kulit (moulting) dengan pemberian kapur pada tambak. }\end{array}$ \\
\hline Udang Gripis & $\begin{array}{l}\text { Pencegahan pada penyakit ini dapat dilakukan dengan cara memberikan } \\
\text { antibiotika melalui pencampuran dengan telur ayam atau telur bebek } \\
\text { mentah dengan perbandingan } 1 \text { butir telur untuk } 10 \mathrm{~kg} \text { pakan. } \\
\text { Campuran telur dan antibiotika diaduk dengan pakan dan dikeringkan } \\
\text { ditempat yang teduh lalu ditebar ke dalam tambak. Dosis yang } \\
\text { digunakan untuk penggunaan antibiotika adalah Terramycin } 30 \mathrm{mg} / \mathrm{kg} \\
\text { pakan, Erythromycin } 40 \mathrm{mg} / \mathrm{kg} \text { pakan, Oxytetracyclin } 40-50 \mathrm{mg} / \mathrm{kg} \\
\text { pakan, Furanace } 100 \mathrm{mg} / \mathrm{kg} \text { pakan.Pemberian antibiotika dalam pakan } \\
\text { dilakukan terus-menerus selama } 3 \text { hingga } 5 \text { hari, kecuali untuk furanace } \\
\text { diberikan selama } 14 \text { hari. }\end{array}$ \\
\hline Kepala Kuning & $\begin{array}{l}\text { Upaya pencegahan yang dapat dilakukan terhadap penyakit ini adalah } \\
\text { dengan melakukan tindakan mengisolasi daerah yang sedang terserang } \\
\text { penyakit serta pemusnahan dengan jalan pembakaran dan penguburan } \\
\text { terhadap udang yang terindikasi terserang penyakit agar penyakit tidak } \\
\text { menyebar luas. Kemudian melakukan upaya penanggulangan agar }\end{array}$ \\
\hline
\end{tabular}


Nama Penyakit

Taura Syndrome Virus
Solusi Pencegahan

udang yang masih sehat terhindar dari serangan penyakit bintik putih, yaitu dengan cara mengganti air secara rutin setiap hari minimal $5 \%$ dari total volume air tambak.

Upaya pencegahan yang dapat dilakukan yaitu dengan menjaga kualitas air dengan memberikan probiotik, jangan lakukan sirkulasi pergantian air, mengurangi pakan hingga 50\%, pemberian mineral dolomite untuk mempercepat pengerasan kulit, serta pemberian vitamin dan imunostimulan.

a) Penentuan permasalahan yang cocok

Sistem pakar untuk mendiagnosa penyakit udang vannamei sangat dibutuhkan oleh petugas tambak untuk dapat mengetahui jenis penyakit yang menyerang udang, dan layak untuk dapat dikembangkan dikemudian hari oleh peneliti-peneliti lain. Permasalahan yang mendasar pada pembuatan sistem ini adalah bagaimana memasukkan kepakaran seorang ahli dibidang penyakit udang ke dalam sistem komputer.

b) Alternatif dalam pembuatan sistem pakar

Dalam mempertimbangkan alternatif pembuatan sistem pakar ini ada dua hal yang perlu diperhatikan, yaitu :

1) Alternatif software yang dibutuhkan, yaitu software yang mampu mengatasi masalah dalam pengelolaan basis aturan sesuai dengan obyek penelitian.

2) Segi manfaat dalam pembuatan sistem pakar tentang jenis penyakit udang vannamei bagi pemakai yang memanfaatkanya. Apabila sistem mampu untuk menggantikan peran dan fungsi dari seorang pakar udang serta mampu memberikan hasil yang tepat kepada pemakai maka sistem pakar tersebut layak untuk dikembangkan.

\subsection{Analisis Kebutuhan}

Analisis kebutuhan adalah bagaimana membuat sistem pakar yang dapat memenuhi kebutuhan pemakai sistem atau user yang terdiri dari :

a) Membuat sistem pakar yang dapat mendeteksi penyakit udang jenis Vannamei berdasarkan gejala-gejala klinis.

b) Membuat sistem pakar yang dapat menggantikan seorang yang ahli dibidang penyakit udang vannamei sehingga dapat membantu petugas tambak di UD. Toriz Putra.

\subsection{Hasil}

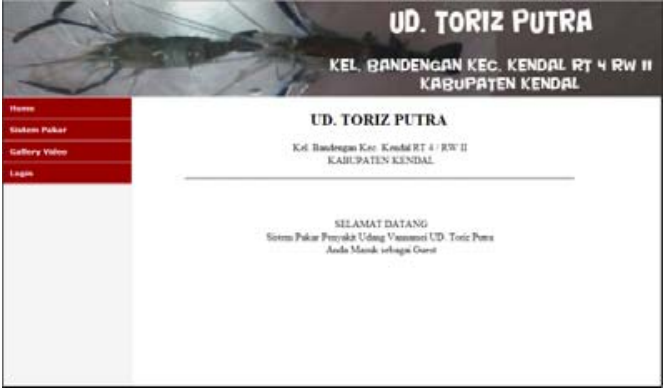

Gambar 4. Menu Pembuka Untuk Guest

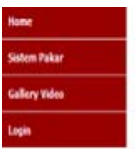

ID. TORIZPITRA

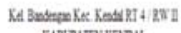

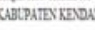

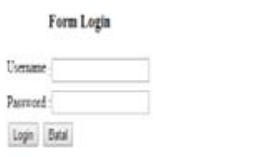

Gambar 5. Menu Login 


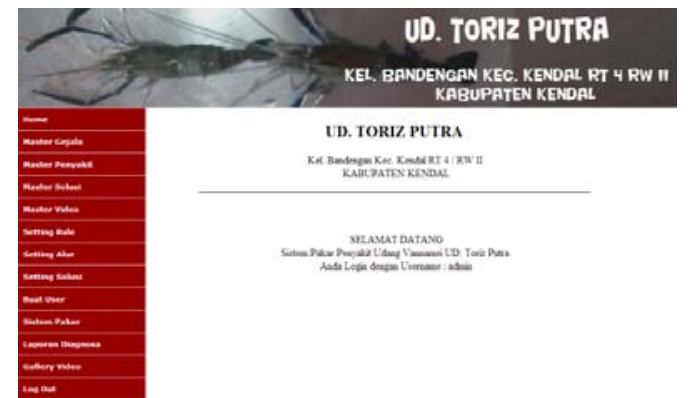

Gambar 6. Menu Pembuka Untuk Admin

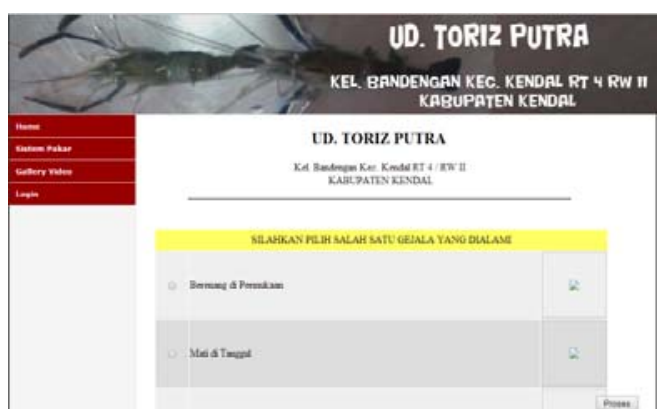

Gambar 7. Menu Inputan Gejala

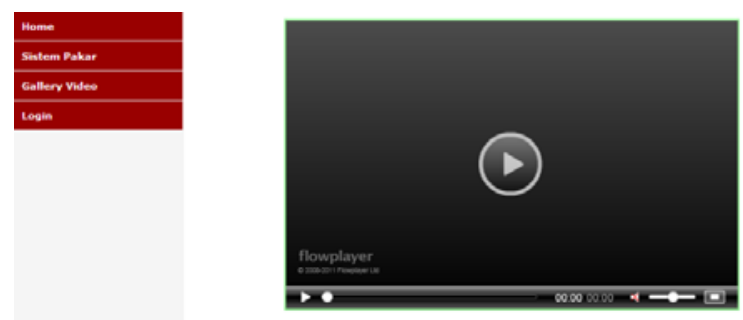

Gambar 8. Menu Video Tentang Udang

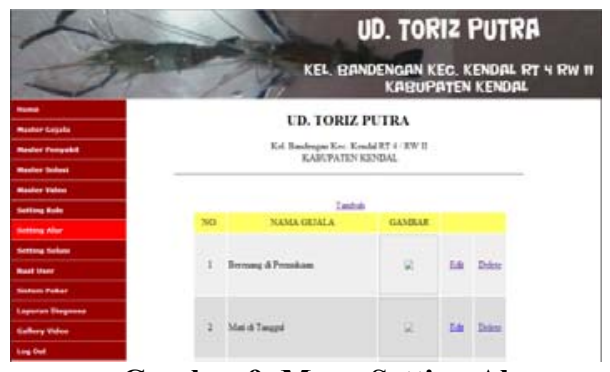

Gambar 9. Menu Setting Alur

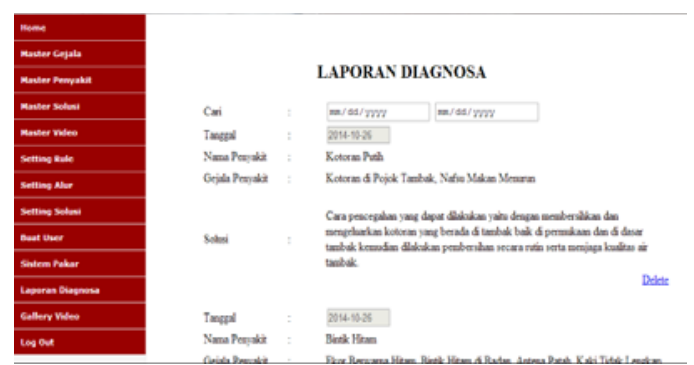

Gambar 10. Menu Laporan Diagnosa

\section{KESIMPULAN}

Kesimpulan dari penelitian yang telah dilakukan di UD. Toriz Putra antara lain yaitu:

a) Berdasarkan nilai validasi dari pakar udang dengan nilai validasi 2,9 yang tergolong dalam kategori valid, dan hasil validasi dari 10 responden dengan nilai 2,92 yang tergolong dalam kategori efektfif, maka dapat disimpulkan bahwa sistem pakar yang dibangun pada penelitian ini efektif dan efisien digunakan petugas tambak mendiagnosa jenis penyakit yang menyerang udang jenis vannamei berdasarkan gejala-gejala klinis.

b) Berdasarkan nilai validasi dari pakar sistem dengan nilai validasi 3,4 yang tergolong dalam kategori sangat valid, maka dapat disimpulkan bahwa sistem pakar yang dibangun pada penelitian ini dengan menggunakan metode forward chaining sudahvalid.

\section{DAFTAR PUSTAKA}

[1] Arhami, Muhammad, 2005; "Konsep Dasar Sistem Pakar", Yogyakarta : Andi,.

[2] Mandiri, Tim Karya Tani, 2009; "Pedoman Budidaya Tambak Udang", Bandung : CV. Nuansa Aulia,.

[3] Marimin, 2005; “Teori dan Aplikasi Sistem Pakar dalam Teknologi Manajerial”, Bogor : IPB Press,.

[4] Setyabudi, Darmawan, Sitanggang, Imam S., Herdiyeni, Yeni, 2010; "Sistem Pakar Diagnosa Penyakit Udang Windu ( Penaeus Monodon) Menggunakan Logika Fuzzy", Jurnal Ilmiah Komputer, Vol 14, No. 1, Mei 2010 : 10-15,

[5] Sugiyono, 2008; “Metode Penelitian Kuantitatif Kualitatif dan R\&D”, Bandung : CV. Alfabeta,. 